\title{
The Social Credit System of the People's Republic of China through the Eyes of Foreign Researchers
}

\author{
Julia P. Bayer, Valeria A. Vasilyeva, Inna A. Vetrenko* \\ Russian Presidential Academy of National Economy and Public Administration (North-West Institute \\ of Management, Branch of RANEPA), Saint-Petersburg, Russian Federation; *vetrenko-ia@ranepa.ru
}

\section{Байер Ю. П., Васильева В. А., Ветренко И. А. *}

Российская академия народного хозяйства и государственной службы при Президенте Российской Федерации (Северо-Западный институт управления РАНХиГС), Санкт-Петербург, Российская Федерация; vetrenko-ia@ranepa.ru

\begin{abstract}
The purpose of this article is to identify and analyze the ideas currently available in world science and practice among foreign researchers on the Social Credit System (SCS). The article analyzes the basic principles of SCS, which allowed us to draw the following conclusions: the social credit system for China is very close to ours mentally and historically, it fits well with the management paradigm based on the principles of Confucianism and Taoism, its main task is to promote the formation of citizens' behavior based on openness, following rituals.

The main conclusions are made, such as the fact that this system allows you to put into practice the principle of the golden mean, that the application of SCS will contribute to the formation of citizens' behavior on the basis of openness, following rituals and the desire for peace of mind. The formation of the population's habit of living in the context of SCS, as the authors believe, will help to increase the sincerity of life. An analysis of the materials of foreign researchers was carried out in the article, which gave reason to conclude that the social credit system, launched in China, so far scares the rest of the world. In this regard, the article discusses the five main fears associated with SCS, as well as the five advantages of introducing this system, draws conclusions, and develops recommendations.
\end{abstract}

Keywords: social credit, social trust, social management, social control, social credit system

For citing: Julia P. Bayer, Valeria A. Vasilyeva, Inna A. Vetrenko. The Social Credit System of the People's Republic of China through the Eyes of Foreign Researchers // Administrative consulting. 2020. No. 7. P. 20-31.

Для цитирования: Julia P. Bayer, Valeria A. Vasilyeva, Inna A. Vetrenko. The Social Credit System of the People's Republic of China through the Eyes of Foreign Researchers // Управленческое консультирование. 2020. № 7. С. 20-31.

\section{Introduction}

The social credit system (hereinafter - SCS), created and introduced in the People's Republic of China, is a widely discussed topic in the world community. Human rights defenders, statesmen and, of course, scientists of various specializations have an increased interest in this phenomenon. However, despite significant public resonance, this problem has been poorly worked out from a scientific point of view. There are still few serious, in-depth analyzes of the social credit system launched in China, in the world. In part, this may be because the system was fully operational only in 2016.

The purpose of this article is to identify and analyze prevailing points of view among foreign researchers at the SCS.

It should be noted that the attitude of foreign researchers to the "Chinese system", as it is often called by foreign authors, is ambiguous, and most importantly, is very different from the attitude of the inhabitants of the China Republic. 
In our study, we used the methods of content analysis of publications placed in scientific citation indices ( $\mathrm{RSCl}$, Scopus, Web-of-Science), as well as scientometric methods and special tools for assessing the data array on the topic under study. The main method was a critical analysis, with the help of which it was possible to identify and analyze all the arguments for and against SCS.

\section{The origins of China's social credit system: background}

China belongs to the traditional eastern civilizations, respectively, what is happening in this state has deep mental and historical roots. For the first time, the need to deploy and implement a Social Credit (trust) System - SCS (international abbreviation) was formulated in 2007 by the former PRC President Hu Jintao. On his initiative, the first technical plan for the deployment of the system was developed, and in the same 2007, "Some comments from the Office of the State Council of the China Republic about the creation of a social credit system" were published [14, p. 88].

But, as we noted above, the basic principles of SCS are deeply rooted in the Chinese mentality and in the traditions of public administration. Even in the I century B. C. the great Chinese reformer, Shang Yang, ordered the people to split into groups of 5-10 families (so called commune) to observe each other, thus bearing collective responsibility for the crimes committed. And even for minor misconduct, the punishments were severe. The law also prescribed that there should be plates on the doors of houses with a list of all family members, and the elder (the one, being responsible for the commune, mentioned above) regularly reported on all movements of residents to their superiors. This system was called "baojia" and for many centuries it periodically appeared again and again in China - mutual responsibility [9, p. 22].

The dispute that has been going on for more than two thousand years between the followers of Shang Yang, the so-called legalists-legists, who advocated the management of society with the help of strict measures (so called whip), and the Confucians, who called for the upbringing of ethical standards among the people through education and a personal example of those in power, became one of the main incentives for the development of management science in China.

Recently, Si Jinping said that the party's strong centralized leadership allowed us to enter a new era of reform and openness, to begin a new path to the great revival of the Chinese nation. In this way party and state leadership relies on the millennia-old tradition of Chinese managerial thought and takes all the best, reliable and tested from the provisions of Confucianism, Legism and Taoism.

Moreover, President of China Si Jinping formulated the "Chinese dream" back in 2013, which meant the idea of creating a prosperous and powerful state, the dream of realizing a national revival and achieving prosperity. In his concept, Si Jinping said that in order to achieve the "Chinese dream" three basic conditions are necessary:

- "It is imperative to follow the Chinese path, that is, the path of socialism with Chinese characteristics. The Chinese nation is a nation of outstanding creativity. Since we managed to create a great Chinese civilization, then, all the more, we will be able to continue and expand the development path corresponding to Chinese realities.

- It is necessary to exalt the unity of the Chinese people, based on trust, the Chinese spirit, the core of which is patriotism, as well as the spirit of the era, the core of which is reform and innovation.

- The forces of the nation, which are born of the great cohesion of 56 nationalities of the 1.3 billion people, should be combined. The Chinese dream is the dream of the whole nation and the dream of each Chinese individually" [13, p. 32].

It is well known that, according to the traditions of Confucianism, trust is a synonym for harmony between a person, society and the state [3; 11]. In turn, harmony is the 
highest duty, goal and need of the Chinese. Harmony is achieved through self-improvement, obeying to the rules of decency and norms of society, and the performance of rituals involving the observance of tradition. As for self-improvement, its key meaning in Confucianism is "overcoming oneself as a separate individual who is being apart from the family, community and people, fulfilling a public duty, pursuing the Chinese dream".

If we analyze the basic principles of SCS, it becomes obvious that this system allows you to put into practice the principle of the golden mean or middle path, which is expressed by:

- compliance with the necessary moderation and rejection of two extremes - excess and deficiency;

- condemnation of all extremes and the desire for a full, open, not having dark secrets life;

- strengthening justice, when not officials or neighbors, but artificial intelligence evaluates misconduct and makes judgments free from bias and one-sidedness;

- development of averaged norms and values that are acceptable to the general population;

- refusal from excessive and unfruitful regulation of all aspects of the life of the Chinese, administration and dependence of the lives of ordinary people on the possible arbitrariness of officials who do not follow party instructions and do not follow the course of the Chinese dream.

Since SCS is the most important contour of party-state administration, the hardwaresoftware solutions in this system must fully comply with the ideology of Chinese management at the present historical stage. SCS, within the framework of the party course and management ideology, should provide the following positions: implementation of the Great Limit principle underlying the Chinese mentality, which implies the interpenetration and removal of opposites, the solution of all issues "according to circumstances" - on a specific situation based on a uniform assessment system for all; accounting, which assumes that the disorder is hidden in the visible order, but in the apparent disorder, on the contrary, the indestructible order is hidden; strengthening the basic interdependence for the behavior of any Chinese in relations between people with each other, with the community, with the party and the state.

The social credit system should also contribute to the implementation, in specific modern conditions, of the most important principle of "following the circumstances of the time", which is largely being absolutized in Taoism. This suggests that: any practice serves to improve oneself (this is true both for individuals and for organizations and SCS itself); the use of SCS will help to shape citizens' behavior based on openness, following rituals and striving for peace of mind; as people develop habits living in SCS conditions, this will help to increase the sincerity of life, and will allow people to at least partially predict the course of events and directions of their own lives.

Thus, the SCS is not a new form of establishing order in China, but a harmonious continuation of the management traditions in this country, which has mentally and historically matured. That is why they do not cause rejection among the inhabitants of the Middle Kingdom, but are not entirely clear to representatives of other countries, which forms such different, and sometimes even counterattack, assessments of SCS, including among the scientific community.

\section{Review of scientific literature and approaches to the social credit system of the PRC}

On 27 of June, 2014, the "Plan (Circular) for the Construction of the Social Credit System for 2014-2020" was officially published. Thus, the State Council of the PRC planned to introduce and disseminate SCS throughout the country by 2020 , when every citizen 
will be evaluated according to his "creditworthiness" and "loyalty" using quantitative indicators (points) based on the historical and current social and economic activities of the citizen, and these credit ratings will determine whether a citizen can receive benefits, or should to be punished somehow [36].

Despite the fact that the crucial document "The program of building a social credit system" was published in 2014, back in 2007, "Some comments from the Office of the State Council of the PRC on the creation of a social credit system" were published. However, this document in the scientific world did not receive a more or less noticeable response then.

Of course, credit scoring issues, or rather, the use of information technology to determine customer reliability, were investigated much earlier, from the 70 -s of the last century. But only after 2007 and only in China, big data technologies (bigdata) were aimed at collecting information about each citizen in order to determine reliability not only financially, but also in all spheres of human activity. For example, in Rongcheng (Shandong Province), a successful social credit system takes into account everything - from the facts of traffic violations to the inability to take care of elderly parents [37].

The very name of the system using the phrase "social credit" is already ambiguously perceived outside of China, since there are certain differences in terminology. In the West, and in Russia, the term "credit" is most often understood as a system of deferred payments. In the Chinese language, in addition to the generally accepted economic meaning, the term "credit" also reflects the social meaning - ethical standards and codes of conduct that citizens must observe throughout their lives, that is, the relationship "citizen - citizen" and "citizen - society" based on ethics. In other words, "social-credit relations of all entities constitute the credit environment and the social order of the whole society" [27].

While the status of a credit entity in the economic sense can change as a result of any unlawful or non-documented actions (defaults, fraud, etc.), the status can be changed socially due to such illegal or unethical action. And both in the banking system, information (credit history, work experience in one place, etc.) is the basis of trust in a client, so in the social credit system in China, trust is based on information on a citizen's daily life.

It is this aspect that worries most of those who have absorbed the Western values of freedom. Total control, interference in personal life, tracking movements, purchases, social circle - someday this will certainly become a weapon in the hands of either scammers, or, even worse, criminals.

The first articles on the ideas of "social credit" appeared in 2006 [43], but until 2017 interest in this topic could not be called massive. Separate articles are being published, and these are mainly articles by researchers from China that describe either the operation of this system, its features and forecasts of the development of relations between the citizen and the state [35; 41; 46], or discuss the SCS in the light of political issues [39].

And only in 2018 did a series of articles appear (11 publications in the Scopus database) that describe the system in detail, on the one hand $[23 ; 36 ; 42 ; 44]$ and the attitude of scientists to this Chinese phenomenon, on the other [20; 26; 40; 47]. In 2019, according to Scopus, 24 articles have already been published. We predict that the number of studies will continue to grow exponentially, since on the Internet they both are being actively discussed - the positive effect of the introduction of the system and citizens of the Middle Kingdom who are satisfied with SCS [25; 30; 45], as well as the fears of outside observers who see the principles of the social credit system as a threat to democratic ideals and economic stability [24; $26 ; 29 ; 32 ; 34]$.

The Asian Institute for Political Studies (South Korea) expressed particular concern, proposing that the new system be called not a system of social credit, but a system of social control [38]. In a research paper "Orwell's Nightmare: China's Social Credit Sys- 
tem", AIPS scientists anxiously recounted "disturbances" in public life (crossing the road on the red light, staying on the Internet for a long time playing video games, late payment of bills) for which Chinese citizens are being reduced points are concerned about the total control that should be ubiquitous under such a system and that applies to all citizens without exception. In addition to the conviction that such a control system is in principle unacceptable in democracies, the authors suggest that corruption in China will only intensify, as you can always find ways and people to change their score, or make adjustments to reporting.

However, after a large case study conducted in 2019 [31], it turned out that about $80 \%$ of the Chinese population approve the system and are convinced that points are awarded impartially and fairly. In addition, in Rongcheng, where the social credit system has been operating for more than 5 years, tax conflicts and disputes have decreased by $22.8 \%$, and population satisfaction has become higher than $96 \%$. The study was organized through websites and asked questions to Chinese people about their attitude to SCS. The results of this study confirm the hypotheses of researchers $[34 ; 36]$ that for the citizens of China, the new system provides more advantages than inconvenience or fear for the leak of confidential information.

While other studies indicate that the emerging SCS is being designed as a "state surveillance infrastructure" [21; 22] and as an instrument of social management [28; 36], the article by a German researcher Genius Kostka [31] emphasizes that these goals are not priority in the minds of Chinese citizens. The study shows that SCS is already widely used in China - more than $80 \%$ of respondents use commercial SCS and $7 \%$ of respondents report local self-government participating in SCS of [31, p. 1573], while the population shows a very high level of approval by the system. For example, $80 \%$ of respondents either unequivocally or with a high degree of confidence approve SCS. Only $19 \%$ of respondents perceive SCS as neutral, while only $1 \%$ reported that they clearly do not approve of SCS. Of course, it is likely that the answers reflect some caution among respondents living under an authoritarian regime. Despite the fact that the survey participants were informed that the questionnaires were anonymous and the research was purely scientific, it is likely that some of the respondents did not express their disapproval by the SCS system. To correct such errors, the researchers conducted a series of interviews with people of different ages, which also showed high levels of approval by the population of the SCS.

Interestingly, strong supporters of CSC are generally older, have higher incomes, are male gender, are more highly educated and live in urban areas.

At first sight, it seems illogical that wealthier and more educated citizens support state and private SCSs, since it is precisely these that potentially affect economic, political, and social freedom and citizens' capabilities. One explanation for such a high degree of approval may simply be that the richer educated citizens have technical knowledge and are more open to technological change. In addition, more educated and wealthy citizens, especially in urban areas, have access to a wider range of benefits provided by the SCS, and the system itself is perceived not as an instrument of supervision and the use of confidential data, but as a tool to improve the quality of life leading to a more honest and law-abiding social behavior.

The view of researchers in other countries carries a significant share of skepticism regarding the "honesty" and transparency of citizens' assessments. A research team from Munich (Germany) [24] analyzed about 200,000 behavioral records and citizen behavior reports published on the official website of the Beijing Social Credit System, and revealed a significant asymmetry between the description of the events of "good" and "bad" behavior. Scientists have found that the cause investigative relationships in the case of inappropriate behavior are described in more detail and more thoroughly. 
In general, an analysis of the materials of foreign, mostly American and European researchers, gives reason to conclude that the social credit system, launched in China, so far scares the rest of the world. And if researchers agree with the need to receive information about a citizen in terms of their financial viability or credit history, penetration into the personal lives of citizens, whether it is recognition of people on the street, behavior, preferences, friends, etc., already refers the Chinese system to a field of outright fear [18; 19; 33].

Russian researchers drew their attention to SCS in China also relatively recently. Since 2018 , a number of publications appear, describing the system of social credit itself [1; $5 ; 7]$ and its assessment in terms of viability [4;6], risks and prospects [17], the impact on international relations in the world [15], as well as the possibility of introducing a similar system in Russia [12].

An analysis of Russian-language scientific publications on the issues of the PRC social credit system shows that the attitude towards it in the post-Soviet space is more calm and even loyal. There are no frank fears or negative assessments; rather, the authors agree that this system still needs to be studied and constantly monitor the progress of its development in China. Burilina M.A. [4] points out the imperfection of the system, which is designed to accustom citizens to self-discipline, and expresses the opinion that in Russia and Europe it will not be easy to introduce such a system due to differences in mentality, religions, moral standards and rights. However, the "social credit" method would, in her opinion, be very useful in resolving migration issues in Europe. Timofeeva E. A. [17] points to the positive effect expected by the Government of China from the introduction of SCS in the country in the form of strengthening sincerity in the interaction of the state, business and people, in stabilizing the legal system. Grigorenko O. and Zhulev F. [7], describing life with a "social credit", noted that citizens who have so to say, "right way of life" have much more opportunities to get a good education, succeed in business, receive rewards, so that Chinese themselves are pretty satisfied with this system.

Pashkovskaya I.V. and Valentseva N.I. [12], comparing the reputation systems of China and Russia, they note only the difference in the set of indicators and the scale of the data, pointing to the obvious advantages of introducing a full-fledged credit scoring system. The last but not the least, SCS of China is also welcomed by scientists because its full functioning is based on the use of "big data", information and communication technologies and their implementation in business projects common in China and not only (Alibaba, WeChat, etc.), that is, SCS contributes to the "further technologization of society" [5]. Moreover, scientists [6; 8; 13] with varying degrees of doubt say that it is impossible to use the SCS of China in Russian conditions "as it is" and emphasize the need to proceed from a different state system in Russia, Russian traditions and values.

From a juridical point of view, the problem of applying fiduciary ratings was considered by D. Beloborodov [1]. He noted that such a moment of "rating" citizens as denunciation has very dubious prospects, despite the fact that the Chinese themselves believe that denunciation in the legal and industrial spheres will work to increase the growth of the citizen's moral consciousness. Pointing out the changes in the concept of morality (according to the practical experience of China today, morality is money), the author concludes that the introduction of high-tech means of monitoring, for example, former convicts, would be a very promising project for Russia.

A number of publications that give a varying degree of negative assessment of the CCK were reviewed by $A$. Bespalko [2]. He made a convincing conclusion about the predominantly emotional nature of such critical evaluations. In the article "On the issue of criticism of the social credit system", the author lists standard theses from critics of the social credit system and, analyzing, argues for their failure.

From our point of view, we will try to do more profound analysis further on. 


\section{Analysis of the pros and cons of the social credit system}

Due to the fact that the main purpose of this article is to carry out a well-reasoned analysis of the social credit system in the PRC, we will turn directly to it as a system designed to create conditions for the open social existence of society:

Contra 1. The system of social credit can deprive citizens of their rights, which is wrong and violates the principle of social justice, which is traditionally insisted on by the management system in a given country [2].

Pro 1. Throughout the world, even without the participation of electronic systems, on the basis of the law, citizens are deprived of their rights: parental, property, driving license, right to hold certain positions, purchase alcohol and cigarettes, etc. In case of offenses, citizens are limited their freedom movement, imprisonment. Many countries still use the death penalty.

Contra 2: The social credit system deprives citizens of their personal privacy. It is not the fact of collecting information that matters (we can't help it anymore), but the question: who will use this information and how. What information and for how long is stored, to whom and on what grounds can or should be transmitted. And, finally, the most important thing: who and how will control the implementation of the rules for processing, storage and use of this information.

It is interesting that the fact that our personal life has long ceased to be only our "personal" is often perceived as a fact with which we can not do anything. In order to ensure security in societies (in all, European, American, Russian and Chinese, etc.) after a series of terrorist attacks, security measures and, accordingly, ways to control our lives have intensified so much and toughened up, that we already perceive it as a bio-survival given, as a necessary measure to ensure our security of our lives on the part of the government of any country. Therefore, the "inviolability" of personal life has long been essentially violated for a long time, and in return, our promised security is that "currency" that we pay, allowing the state to control us in this [48]. Therefore, the SCS is just one more direction, where can one can use the data, since they already exist and are already in use.

Pro 2: The social credit system itself does not create any new data about a specific person, it systematizes the existing data. Just like an HR-specialist, before inviting a candidate for a final interview, monitors the social accounts of the candidate, his friends, his popularity, his activity in social networks. The same does the social credit system: also monitoring the information already available on the network.

No matter how sad it sounds, but if we don't know ourselves, then Google or any other search engine had done it for a long time. Whether we make requests, we keep friends' contacts, we watch videos - Google remembers and structures everything, gives us contextual advertising, clips specially selected for us, music, movies, offers friends on social networks, etc. The social credit system uses what global firms and the global market have long been using for promoting their products and services; they simply have not made a statement about it (didn't make it loud).

Banks store data about customers and all financial transactions, stores collect information about citizens' purchases (loyalty programs, bonus systems and so on). Uber, Booking, Trip Adviser know everything about our movements, Pedometer on the phone about calories spent, and Fat Secret - about calories intake, etc. This is stored in our phone, the data of which is constantly updated, transmitted, processed. Thus, at present, talking about personal privacy is ridiculous and pointless, the only thing we can do is that, becoming public, we should not be ashamed of our life and the facts of the biography in it. Under the term publicity in this case we understand social rating as well.

The social credit system by itself does not create new data about society and the citizen, for the most part it receives and processes information already available in 
other social and commercial institutions. That is why one of the first providers of information for the work of SCS in China was the world's largest online platform trading with Sesame Credit's own rating service.

Not a social credit system deprives people of their privacy, but new technologies in the service of banks, Internet providers, mobile operators, social networks, online stores, trade and transport organizations, and others. The social credit system evaluates people according to these parameters, which is why it causes such a wave of criticism. It is one thing to simply own information, and another to use it to evaluate and rate citizens, creating a justified stratification of our information society. People do not like to be evaluated and compared with others. The basis of the negative attitude towards this, from our point of view, is fear of non-compliance, fear of being worse than others.

Contra 3: Evaluating people is inhumane because everyone is equal. This thesis is gaining its popularity especially in Western European countries. The authors of the article remain supporters of P. A. Sorokin's classical theory of social stratification [16], who convincingly proved that we are already born unequal, that social equality is a utopia. Since the great sociologist wrote his work, little has changed; we continue to dwell by three main parameters of the stratification of society: economic, political and professional. Unless social elevators, due to the transition of society from industrial to informational (postindustrial), from Christian to post-Christian, have changed. This topic requires a separate careful presentation, so we are not talking about it.

Pro 3: We are born not equal, this was described in detail by the mentioned above classic P.A. Sorokin, having convincingly developed the theory of social stratification and social mobility [16]. We evaluate people and they evaluate us. We evaluate schoolchildren, students, workers. Everyone gets different grades, different salaries, different accesses to social benefits. The methods for assessing personnel are very well developed: interviews, assessment-center, 360 degrees, KPI, etc. These and many other methods for evaluating candidates or existing employees are no different from what the social credit system does. Both social credit and the HR specialist set as their goal the obtaining of a comprehensive assessment of the candidate, including in the aspect of reliability. Now it doesn't occur to anyone to protest against the assessment when applying for a job, everyone considers this to be well-established and perfectly normal. At the same time, social credit will simplify the work of HR specialists, since the accumulated social credit will speak for the employee better than he does for himself in an interview (giving socially expected answers to the tricky questions of the employer, for example).

Contra 4: the assessment system is like "the last judgment in life," it will destroy social ties.

Pro 4: The social credit system actually has already entered our lives, together with the rapidly developing and already thriving sharing economy. Let's think, will we rent a house through Airbnb for a person with three negative and one positive feedback? No, because his "social credit" is mostly negative. Will we deal with a couchsurfer on the Couchsurfing website if he has five negative reviews? And with one that has 300 reviews and all are positive? And finally, we most often cancel the order at Uber, if the driver rating is below 4.5, and if its rating is below 4.0, then the system itself "turns him off". There are many such applications, without having studied the rating and without having read the reviews, we do not even begin communication with the person. None of the application users have ever complained about the existence of a rating and a feedback system in them. On the contrary, all sharing is based on such sites, interpersonal communication, reviews and trust. Fear of receiving negative feedback and losing the ability to rent or housing leads to the fact that the participants do even more than is necessary according to the rules (meet guests, conduct excursions, etc.). 
Evaluation and ratings help navigate the social space, give a signal of danger or, conversely, allow you to trust a person based on his "earned karma" / social credit. And the participants themselves know this. Thus, the social credit system should not cause a negative reaction, and if it does, it should be alarming: maybe a person knows that his rating will be low due to his actions? In a modern society where we don't even know our neighbors, social credit will help us to distinguish who is a "person to be trust", and who is not trustworthy.

The social credit system will be converted into a quantitative indicator by the public opinion accumulated by each citizen about it. Of course, such a transition from "quality" to "quantity" cannot but frighten, therefore, an assessment system is important, who evaluates, evaluation parameters, assessment methodology, impartiality of assessment.

We can assume that the presence of electronic "public opinion" will increase the level of trust between people and will allow us to quickly establish interpersonal relationships. Perhaps this will also affect the growth in the number of marriages and the decrease in the number of users of dating sites.

Contra 5: The social rating system is designed to develop and maintain totalitarian and authoritarian societies and is not applicable in democratic countries.

Pro 5: The social credit system, as an accumulated public opinion about each citizen, being transferred into quantitative indicators, can prevent the "negative" citizens from getting into power, that is, having a low value of social credit. If we trust our life to the Uber driver based on information about his experience and rating, then why can't we use the same system when we trust our lives to politics, not for an hour of travel, but for a "trip", 4-5 years long and more? Moreover, having seen the driver's unreliability, we can always ask him to stop the car and leave, but a politician, once being chosen, can't be replaced easily. Moreover, modern PR-technologists can beautifully "pack" any political "product", but when a "product" has a rating that has been created over the years, it will be much more difficult to mislead people with effective technologies.

You can set some "threshold value" of social credit, upon reaching which the candidate can apply for public service (if the social credit system had already existed in Germany in the 1930s, Hitler would not have come to power). And imagine how much social credit will ease the work of HR-specialists, as we have already mentioned. The validity of all kinds of modern assessment methods simply fades in comparison with the public rating that the candidate already has.

The system of social rating will allow to outline most worthy candidates for public service, offering important positions to the most worthy, this will directly reduce the level of corruption.

\section{Conclusion}

The main target function of the social credit system was formulated in December, 2016 by $\mathrm{Si}$ Jinping at a meeting of the Politburo of the Central Committee of the Communist Party of China. He noted: "To combat the acute problem of lack of trust, we need to take a firm hold on creating a system for assessing reliability that covers the society in general. It is necessary to improve both the mechanisms for encouraging law-abiding and conscientious citizens, and the mechanisms for punishing those who violate the law and lose confidence, so that a person simply does not dare, simply cannot lose this trust" [10].

Of course, SCS initiatives are still at an experimental stage, and it is quite possible that public opinion will change as the system develops. It is obvious that the balance of rewards and punishments will influence and will affect the perception of the system. In addition, the transparency of scoring methods is a condition of citizens' trust in the social credit system itself. Already now, the more understandable is the assessment, 
the more impartially it is being fulfilled, the stronger is the public support for the entire project in China.

Our analysis showed that the vast majority of publications reduce the SCS to an assessment of the behavior of only ordinary Chinese, but this is not entirely true. Si Jinping's speeches and normative documents have repeatedly noted that the individual rating system that is being created is no more than just the first step. In the near future, not only Chinese will be rated as individuals, but also companies as legal entities and then various non-profit and management structures and organizations, and their leadership.

The working system of social credit, as conceived by the Chinese leadership, should lead to:

- developing transparent e-democracy;

- faster establishment of trust between members of society;

- responsible attitude to their social behavior, depriving them of feelings of impunity and impersonality;

- meritocracy;

- a transparent system of social stratification.

\section{References}

1. Beloborodov D.V. Legal features of the fiduciary rating of individuals and the prospects for its use in the penal system // Bulletin of the Samara Law Institute [Vestnik Samarskogo yuridicheskogo instituta]. 2018. N 2 (28). P. 9-14. (In rus)

2. Bespalko A. A. On the issue of criticism of the social credit system // Systems and Management [Systemy i Management]. 2019. Vol. 1. N 2. P. 72-80. (In rus)

3. Boyarkina A. V. The ideas of Confucianism in the state ideology of the PRC // Russia and AsiaPacific [Rossiya i ATR]. 2011. N 4. P. 127-136. (In rus)

4. Burilina M. A. The methodology of the formation of artificial societies on the example of social credit // Artificial societies [Iskusstvennye obshchestva]. 2019.Vol. 14. N 2. P. 4. (In rus)

5. Bilyeva D.S. Control as a new function of information and communication technologies // Fourth Industrial Revolution: realities and modern challenges. $X$ anniversary St. Petersburg sociological readings. Collection of materials of the International Scientific Conference. 2018. P. 21-24. (In rus)

6. Galiullina S. D. Social credit system in China as an element of the digital future / Galiullina S. D., Bresler M. G., Muleymanov A. R., Rabogoshvili A. A., Bayramgulova N. N. // Bulletin of the Ufa State Oil Technical University. Science, education, economics. Series: economics [Vestnik Ufimskogo gosudarstvennogo neftyanogo tekhnicheskogo universiteta. Nauka, obrazovanie, ekonomika. Seriya: ekonomika]. 2018. N 4 (26). P. 114-121. (In rus)

7. Grigorenko O.V., Zhulev F.S. The credit of social trust or how China "wrote off" from Orwell // Actual problems of the humanities and socio-economic sciences. Collection of scientific papers of the Institute of Innovative Technologies and Public Administration FSBEI VL "MIREA - Russian Technological University". M., 2019. P. 59-66. (In rus)

8. Danilin P. N., Khilko I.Yu. The history of development and the prospects of introducing a system of social credit (rating) in the People's Republic of China and the Russian Federation // Eurasian Law Journal [Evraziiskii yuridicheskii zhurnal]. 2018. Vol. 123. N 8. P. 48-50. (In rus)

9. Chinese civilization in a globalizing world. Based on the materials of the conference. In 2 vols. / Ans. ed. V. G. Khoros. Vol. 1. M. : Institute of World Economy and International Relations of the Russian Academy of Sciences, 2014. (In rus)

10. Kovalich L. Big brother 2.0. How China is building a digital dictatorship. The Carnegie Moscow Center [Electronic resource]. URL: https://carnegie.ru/commentary/71546 (accessed: 28.01.2020). (In rus)

11. Kondrashova L.I. Chinese dream of national revival. M. : Institute of Economics, RAS, 2014. (In rus)

12. Pashkovskaya I. V., Valentseva N.I. Development of a reputation scoring system based on the example of China and Russia // Bulletin of Eurasian Science [Vestnik Evraziiskoi nauki]. 2019. N 2. (In rus) 
13. Burnt A.P. Russian ideology: a search among alternatives // Scientific Thought [Nauchnaya mysl']. 2016. N 1 (19). P. 26-32. (In rus)

14. Razumov E. A. Digital dictatorship: features of the social credit system in the People's Republic of China // Proceedings of the Institute of History, Archeology and Ethnography, Far Eastern Branch of the Russian Academy of Sciences [Trudy instituta istorii, arkheologii i etnografii DVO RAN]. 2009. Vol. 24, N 3. P. 86-97. (In rus)

15. Rinchinov A. B. "Chinese Dream" by Xi Jinping in the Context of the National Construction of the Peoples Republic of China // Bulletin of the Trans-Baikal State University [Vestnik Zabaikal'skogo gosudarstvennogo universiteta]. 2018. Vol. 24. N 6. P. 89-94. (In rus)

16. Social mobility. Pitirim Sorokin. Translation from English by M. V. Sokolova. M. : Academia, LVS, 2005. (In rus)

17. Timofeeva E. A. Expected results, problems and risks of implementation in the PRC "System of social credit" // Academy of Law and Economics [Akademiya prava i ekonomiki]. 2018. N 3 (7). P. 22-25. (In rus)

18. Bolt J. Social Credit Score // Institute of Public Affairs Review. 2018. Vol. 70. N 3. P. 66.

19. Botsman R. Big data meets Big Brother as China moves to rate its citizens [Electronic resourse]. URL: https://www.wired.co.uk/article/chinese-government-social-credit-score-privacy-invasion (accessed: 28.01.2020).

20. Creemers R. Disrupting the Chinese State: New Actors and New Factors // Asiascape: Digital Asia. 2018. N 3 (5). P. 169-197.

21. Dai, X. Toward a Reputation State: The Social Credit System Project of China. 2018 [Electronic resourse]. URL: https://ssrn.com/abstract=3193577 (accessed: 28.01.2020).

22. Diab R.S. Becoming-Infrastructure: Datafication, Deactivation, and the Social Credit System // Journal of Critical Library and Information Studies. 2017. N 1.

23. Domingo-Ferrer J. Privacy-preserving and co-utile distributed social credit. In: Brankovic L., Ryan J., Smyth W. (eds) Combinatorial Algorithms. IWOCA 2017. Lecture Notes in Computer Science. Vol. 10765. Springer, Cham Combinatorial Algorithms. 2018. P. 371-382.

24. Engelmann, S., Chen, M., Felix Fischer, F., Kao, P., Grossklags, J. Clear Sanctions, Vague Rewards: How China's Social Credit System Currently Defines "Good" and "Bad" Behavior. In Proceedings of the Conference on Fairness, Accountability, and Transparency (FAT* '19). Association for Computing Machinery. New York, 2019. P. 69-78.

25. Fan W. [at al]. A framework for automatic collection and updating of "Honor \& Black» list based on big data // IEEE 4th International Conference on Cloud Computing and Big Data Analysis (ICCCBDA), Chengdu, China, 2019. P. 472-476.

26. Jiang M., Fu K.-W. Chinese Social Media and Big Data: Big Data, Big Brother, Big Profit? // Policy and Internet. 2018. N 4 (10). P. 372-392.

27. Han J. The Meaning and Extension of Social Credit System // China's Reform Daily. 2014. July 28 [Electronic resource]. URL: http: //www.crd.net.cn/2014-07/28/content_12207041.htm (accessed: 28.01.2020).

28. Hoffman, S. Managing the State: Social Credit, Surveillance and the CCP's Plan for China // China Brief Volume. 2017. Vol. 17. N 11.

29. KasI F. Surveillance in digitalized society: The chinese social credit system from a European perspective // Lawyer Quarterly. 2019. N 4 (9). P. 349-358.

30. Keane M., Su G. When push comes to nudge: a Chinese digital civilisation in-the-making // Media International Australia. 2019. N 1 (173). P. 3-16.

31. Kostka, G. China's social credit systems and public opinion: Explaining high levels of approval // New Media \& Society. 2019. N 21 (7), P. 1565-1593.

32. Laband, J. How Can Individuals, Companies Be Limited by Bad Social Credit in China? // China Business Review, Feb. 2017 [Electronic resourse]. URL: https://www.chinabusinessreview.com/how-can-individuals-companies-be-limited-by-bad-social-credit-in-china/ (accessed: 28.01.2020).

33. Lee P.S. Datafication, dataveillance, and the social credit system as China's new normal // Online Information Review. 2019. N 6 (43). P. 952-970.

34. Lee J.W. Your life is number // Psychology today. 2019. N 7-8. C.72-81.

35. Li J.H. Service innovation research in China: Past, present and future // Journal of Science and Technology Policy in China. 2012. Vol. 3. N 1. P. 68-91.

36. Liang F., Das V., Kostyuk N., Hussain M. M. Constructing a Data Driven Society: China's Social Credit System as a State Surveillance Infrastructure // Policy \& Internet. 2018. N 4 (10). P. $415-453$. 
37. Mistreanu S. Life Inside China's Social Credit Laboratory [Electronic resourse]. URL: http://foreignpolicy.com/2018/04/03/life-inside-chinas-social-credit-laboratory/ (accessed: 28.01.2020).

38. Orwell's Nightmare: China's Social Credit System // The Asan Institute for Policy Studies. 2017 [Electronic resourse]. URL: http://en.asaninst.org/contents/orwells-nightmare-chinas-socialcredit-system/ (accessed: 28.01.2020).

39. Qi, M. Problems of Building a Social Credit System and A Way-out // Modern Management Studies (Xiandai guanli kexue). 2016. N 10. P. 76-78.

40. Ramadan Z. The gamification of trust: the case of China's "social credit" // Marketing Intelligence and Planning. 2018. N 1 (36). P. 93-107.

41. Ruan L., Tian, D. A research of trust based on e-commerce // Proceedings of the International Symposium on Electronic Commerce and Security. ISECS 2008. P. 776-779.

42. Sazonets I. L., Hanin I. G., Ryabokon M. V., Pikalov Y.V. Efficiency of digital public administration system in the course of implementing the innovative potential of national economy // Journal of Social Sciences Research. 2018. Special Is. P. 542-548.

43. Sui S.-X., Wang P.-Y. 2006. Constructing of Social Credit System in Chinese Market Economy Demands Essential Functions of the Administration for Industry and Commerce // 2006 International Conference on Management Science and Engineering, Lille, 2006. P. 2245-2249.

44. Xavier M.A.S., Ferreira F.A.F., Esperança J.P. An intuition-based evaluation framework for social credit applications // Annals of Operations Research. 2018 [Electronic resourse]. URL: https://idp.nwipa.ru:2188/10.1007/s10479-018-2995-8 (accessed: 28.01.2020).

45. Xu D., Ma J., Xu J. Structuring China business credit management system and relevant characteristic variables based on the tree model // International Journal of Information Systems and Supply Chain Management. 2019. N 2 (12). P. 22-35.

46. Yanying Z., Qian Y. College students' behaviors of net loans: Status, problems and countermeasures-based on 486 questionnaires of 6 universities // Proceedings of the 2018 9th International Conference on E-business, Management and Economics. 2018. P. 86-90.

47. Yeoh E. K.-K. Brave new world meets nineteen eighty-four in a new golden age: On the passing of Liu Xiaobo, advent of big data, and resurgence of China as world power // Contemporary Chinese Political Economy and Strategic Relations. 2018. N 2 (4). P. 593-764.

48. Yuval N. H. 21 Lessons for the 21st Century. London, Vintage, 2019. P. 93-98.

About the authors:

Julia P. Bayer, North-West Institute of Management, Branch of RANEPA (St. Petersburg, Russian Federation), Associate Professor, PhD in Sociology; bayer-yp@ranepa.ru

Valeria A. Vasilyeva, North-West Institute of Management, Branch of RANEPA (St. Petersburg, Russian Federation), Deputy Head of the Information and Library Department; vasileva-va@ ranepa.ru

Inna A. Vetrenko, North-West Institute of Management, Branch of RANEPA (St. Petersburg, Russian Federation), Doctor of Political Sciences, Professor, Head of the Department of Social Technologies; vetrenko-ia@ranepa.ru

\section{Об авторах:}

Байер Юлия Паулевна, Северо-Западный институт управления РАНХиГС (Санкт-Петербург, Российская Федерация), доцент кафедры социальных технологий, кандидат социологических наук, доцент; bayer-yp@ranepa.ru

Васильева Валерия Алексеевна, Северо-Западный институт управления РАНХиГС (СанктПетербург, Российская Федерация), заместитель начальника Информационно-библиотечного управления; vasileva-va@ranepa.ru

Ветренко Инна Александровна, Северо-Западный институт управления РАНХиГС (СанктПетербург, Российская Федерация), заведующий кафедрой социальных технологий, доктор политических наук, профессор; vetrenko-ia@ranepa.ru 